\title{
Polyunsaturated Fatty Acid-Mediated Suppression of Insulin-Dependent Gene Expression of Lipogenic Enzymes in Rat Liver
}

\author{
Nobuko IRITANI* and Hitomi FukUdA \\ Tezukayama Gakuin College, Sakai, 590-01, Japan \\ (Received August 10, 1994)
}

\begin{abstract}
Summary The effects of dietary polyunsaturated fat on insulindependent gene expression of lipogenic enzymes and a possible mechanism for PUFA-mediated suppression of the gene expression have been investigated in rat livers. When diabetic rats were injected with insulin, the insulin dose-dependent induction of lipogenic enzyme mRNAs were markedly reduced with increasing dietary corn oil. On the other hand, the PUFA-mediated suppression of the mRNA concentrations was partially restored by treatment with pioglitazone, a candidate for increasing insulin receptor phosphorylation. Moreover, insulin binding to receptors of liver, receptor autophosphorylation, and kinase activity toward exogenous substrate were lower in the corn oil diet group than in the hydrogenated fat group. The PUFA-mediated suppression of insulin binding was somewhat restored by pioglitazone, and the suppression of insulin receptor phosphorylation was significantly restored. It is suggested that the PUFA-mediated suppression of insulin-dependent gene expression of lipogenic enzymes can be ascribed to a decrease in insulin receptor binding primarily and also to receptor phosphorylation. Thus, PUFA appears to suppress the lipogenic enzyme gene expression stimulated by insulin.

Key Words lipogenic enzyme gene expression, pioglitazone, PUFAs, insulin receptors
\end{abstract}

The gene expression of lipogenic enzymes in the rat liver was increased by a fat-free/high-carbohydrate diet and decreased by feeding polyunsaturated fat, fasting or a diabetic state (1-5). The mRNA induction of all the lipogenic enzymes was remarkably reduced by PUFAs, but not by saturated or monounsaturated fatty

* To whom correspondence should be addressed.

Abbreviations: PUFA, polyunsaturated fatty acid; PMSF, phenylmethylsulfonyl fluoride; WGA, wheat germ agglutinin; Glu: Tyr, glutamine and tyrosine polymer.

Enzymes: acetyl-CoA carboxylase (EC 6.4.1.2), fatty acid synthase (EC 2.3.1.85), malic enzyme (EC 1.1.1.40), glucose-6-phosphate dehydrogenase (EC 1.1.1.49), ATPcitrate lyase (EC 4.1.3.8). 
acids $(6,7)$. Although the mechanisms of stimulation and suppression of lipogenic enzyme gene expression have scarcely been elucidated, the concept that the cisacting elements of genes can be involved in the expression is generally accepted (8). Recently, it has been reported that the cis-linked PUFA response elements are localized in the promoter region of the L-pyruvate kinase gene and also in that of S14, which has been used as a model for examining the effects of PUFAs on hepatic lipogenic enzyme gene expression $(9,10)$. Moreover, a carbohydrate response element has already been found in the promoters of the L-pyruvate kinase and S14 genes (11-13). A similar nucleotide sequence also exists in the first intron of the fatty acid synthase gene (13). Recently, an insulin response element has been found in a rat fatty acid synthase promoter (14). However, the PUFA response elements have not been identified in any lipogenic enzyme gene.

On the other hand, we have recently found that lipogenic enzyme gene expression of genetically obese rats, which were less sensitive to insulin $(15,16)$, was not suppressed by PUFA as much as that of lean rats, possibly due to a defect of insulin binding to receptors (17). Cremel et al. (18) reported that linoleic acid decreased insulin binding to receptors in rat hepatoma cells, and tyrosine kinase activity of partially purified receptors from the cells decreased proportionally with the changes in insulin action. Therefore, the insulin receptor activity may be also involved in the PUFA-mediated suppression of lipogenic enzyme gene expression. To elucidate the mechanism, in the present experiment, we have investigated the effects of polyunsaturated fat feeding on the insulin-dependent gene expression in diabetic rat liver and the insulin receptor activity. Moreover, the effects of pioglitazone, a promising candidate for reducing insulin resistance $(15,16,19-21)$, on the lipogenic enzyme gene expression and the PUFA-mediated suppression have been investigated. Subsequently, a possible mechanism for the PUFA-mediated suppression has been suggested.

\section{MATERIALS AND METHODS}

Chemicals. $\left[\alpha{ }^{32} \mathrm{P}\right] \mathrm{dCTP}(111 \mathrm{TBq} / \mathrm{mmol})$ and $\left[\gamma_{-}{ }^{32} \mathrm{P}\right] \mathrm{ATP}(167 \mathrm{TBq} / \mathrm{mmol})$ were purchased from ICN. Nylon filters were purchased from Amersham (Hybond N). Other reagents were mostly from Sigma and Wako Pure Chemical Industries. Pioglitazone was a gift from Takeda Chemical Industries (Japan).

Animals. Male Wistar rats (SLC, Japan), 6 weeks old, were made diabetic by intravenous injection of streptozotocin $(6 \mathrm{mg} / 100 \mathrm{~g})$ after starvation for $20 \mathrm{~h}$. Blood glucose was assayed 3 days after the treatment and rats with blood glucose levels of over $300 \mathrm{mg} / \mathrm{dl}$ were used for experiments. The animals were given a 5 or $10 \%$ fat diet (as indicated in the figure and table legends) for 5 days after the streptozotocin treatment. A fat-free diet contained 67\% glucose, 18\% casein, 9.9\% cellulose, $5 \%$ salts, $0.1 \%$ choline chloride and vitamins (22). A part of the glucose was substituted by fat in the diet containing 5 or $10 \%$ fat. The animals were allowed to take water and diet ad libitum, but consumed similar amounts of the 
diets among the dietary groups. The diabetic rats nibbled during day and night. They were kept under an automatic lighting schedule from 0800 to $2000 \mathrm{~h}$ at $24^{\circ} \mathrm{C}$.

For insulin treatment, animals were subcutaneously injected with $0.625,1.25$, 2.50 , or $3.75 \mathrm{U}$ Lente insulin per $100 \mathrm{~g}$ body weight at $1700 \mathrm{~h}$. The animals were killed $16 \mathrm{~h}$ after the insulin treatment. Pioglitazone, 5-[4-[2-(5-ethyl-12-pyridyl)ethoxy]benzyl]-2,4-thiazolidinedione $(3 \mathrm{mg} / \mathrm{kg} /$ day) was administered by orogastric tube for 5-7 days. A specimen of each liver was immediately frozen to measure the mRNA concentrations. Another specimen of the liver was used for the insulin receptor studies.

Dot blot hybridization assay. The cDNA species of lipogenic enzymes were cloned as described in our previous reports (1-5). Total RNA was isolated from the livers by the guanidium thiocyanate-phenol-chloroform extraction method (23). To measure the mRNA concentrations of lipogenic enzymes, the total RNA $(5-10 \mu \mathrm{g})$ was denatured with formamide, spotted on nylon filters, and then irradiated with ultraviolet light for $5 \mathrm{~min}$. The filter was prehybridized and then hybridized with ${ }^{32}$ P-labeled cDNAs as described previously (3). Relative densities of the hybridization signals were determined by scanning the autoradiograms at 525 nm (Model CS-9000, Shimadzu).

Preparation of partially purified insulin receptors. Insulin receptors were purified from livers essentially according to the method of Kadowaki et al. (24). The livers were homogenized in 3 volumes of $50 \mathrm{mM}$ HEPES buffer ( $\mathrm{pH}$. 7.6) containing $0.25 \mathrm{M}$ sucrose, $1 \mu \mathrm{g} / \mathrm{ml}$ aprotinin, and $1 \mathrm{mM}$ PMSF. The homogenate was centrifuged at $10,000 \times g$ for $20 \mathrm{~min}$, followed by centrifugation of the supernatant at $100,000 \times g$ for $90 \mathrm{~min}$. The pellet was suspended in $50 \mathrm{mM}$ HEPES washing buffer (pH 7.6) containing $1 \mu \mathrm{g} / \mathrm{ml}$ aprotinin and $1 \mathrm{mM}$ PMSF, and was washed twice at $100,000 \times g$ for $60 \mathrm{~min}$. The pellet was stored at $-70^{\circ} \mathrm{C}$ for further purification. For experiments, samples were thawed and solubilized for $60 \mathrm{~min}$ in the presence of $2 \%$ Triton $\mathrm{X}-100$. The insulin receptors were purified using a wheat germ lectin-agarose column. The procedures were carried out at $4^{\circ} \mathrm{C}$.

Insulin binding to receptors. Lectin-purified insulin receptors were incubated with ${ }^{125} \mathrm{I}$-labeled insulin at $4{ }^{\circ} \mathrm{C}$ for $16 \mathrm{~h}$ in the presence of various concentrations of unlabeled insulin in $200 \mu 1$ of $25 \mathrm{~mm}$ HEPES ( $\mathrm{pH} \mathrm{7.6)}$ ) containing $0.05 \%$ Triton X$100,20 \mathrm{mM} \mathrm{NaCl}, 0.05 \mathrm{mg} / \mathrm{ml}$ bovine serum albumin, and $150 \mathrm{~mm} N$-acetyl-Dglucosamine, essentially according to ref. (25). With human $\gamma$-globulin as carrier protein, receptor-bound insulin was precipitated with polyethylene glycol. Nonspecific binding was defined as the radioactivity precipitated in the presence of 3.1 $\mu \mathrm{M}$ unlabeled insulin.

Insulin receptor autophosphorylation and kinase activity. Insulin receptors were purified from livers using wheat germ lectin-agarose as described by Freidenberg et al. (26). Autophosphorylation of the partially purified insulin receptors was performed by the method described in ref. (26). The receptors, containing $7 \mu \mathrm{g}$ of protein, were preincubated with or without insulin at $4^{\circ} \mathrm{C}$ for $16 \mathrm{~h}$ in $40 \mu 1$ of $25 \mathrm{~mm}$ HEPES buffer ( $\mathrm{pH} \mathrm{7.6)} \mathrm{including} 0.05 \%$ Triton X-100, $15 \mathrm{mM} \mathrm{NaCl}, 0.1 \mathrm{mg} / \mathrm{ml}$ 
bovine serum albumin, and then incubated with $30 \mu \mathrm{M}\left[\gamma_{-}{ }^{32} \mathrm{P}\right] \mathrm{ATP}, 2 \mathrm{mM} \mathrm{MgCl}_{2}$, and $15 \mathrm{mM} \mathrm{MnCl}_{2}$. After incubation at $4{ }^{\circ} \mathrm{C}$ for $60 \mathrm{~min}$, the reaction was terminated by the addition of fivefold-concentrated Laemmli sample buffer supplemented with ATP and dithiothreitol (27), and heating to $95^{\circ} \mathrm{C}$ for $3 \mathrm{~min}$. Phosphorylated proteins were analyzed by $7.5 \%$ SDS-PAGE. The gels were stained, dried, and autoradiographed. Radioactivities incorporated into the $95,000-M_{\mathrm{r}}$ protein in the gels were measured by cutting the appropriate regions from the dried gel slabs and counting with a liquid scintillation counter.

In the experiment measuring the insulin receptor kinase activity, after incubation of insulin receptors with varied concentrations of insulin, phosphorylation was initiated by adding $\left[\gamma_{-}^{-} \mathrm{P}\right] \mathrm{ATP}, \mathrm{Mg}^{2+}$, and Glu4 : Tyr1. The reaction was terminated by the addition of unlabeled ATP (final concentration, $50 \mathrm{~mm}$ ). Aliquots of the reaction mixtures were spotted on squares of Whatmann $3 \mathrm{MM}$ paper and washed in $10 \%$ trichloroacetic acid (28). The radioactivities of the dried papers were measured by scintillation counter.

Statistical analysis. Statistical evaluation of the results was carried out by Student's $t$-test or by one-way analysis of variance (29).

\section{RESULTS}

Effects of dietary PUFA on insulin-dependent gene expression of lipogenic enzymes in rat liver

The mRNA concentrations of lipogenic enzyme set: acetyl-CoA carboxylase, fatty acid synthase, ATP-citrate lyase, malic enzyme, and glucose-6-phosphate dehydrogenase were very low in the livers of diabetic rats. However, the mRNA concentrations were restored to normal levels $16 \mathrm{~h}$ after injection of $2.5 \mathrm{U}$ Lente insulin per $100 \mathrm{~g}$ body weight (1-4). To analyze the relative effects of insulin and PUFA on lipogenic enzyme gene expression, the mRNA concentrations in diabetic rats fed a $10 \%$ hydrogenated fat, $5 \%$ corn oil (plus 5\% hydrogenated fat), or 10\% corn oil diet were measured $16 \mathrm{~h}$ after injection of different doses of insulin $(0.625-$ $3.75 \mathrm{U} / 100 \mathrm{~g}$ ). The mRNA concentrations in rats fed the $10 \%$ hydrogenated fat diet were increased by the insulin treatment to levels nearly equal to those in rats fed a fat-free diet (data not shown). However, the insulin-dependent increases of the mRNA concentrations in the 5\% corn oil diet group were about half of those in the hydrogenated fat group, and were lower still in the $10 \%$ corn oil group. The results are shown in Fig. 1.

Comparison of the concentrations of acetyl-CoA carboxylase and fatty acid synthase mRNA after treatment with $2.5 \mathrm{U}$ of insulin (per $100 \mathrm{~g}$ ) in diabetic rats among the groups fed varied fat diets are shown in Table 1. The mRNA concentrations were not significantly decreased by hydrogenated fat or olive oil in comparison to the fat-free diet group, but were markedly decreased by fish oil or corn oil. 


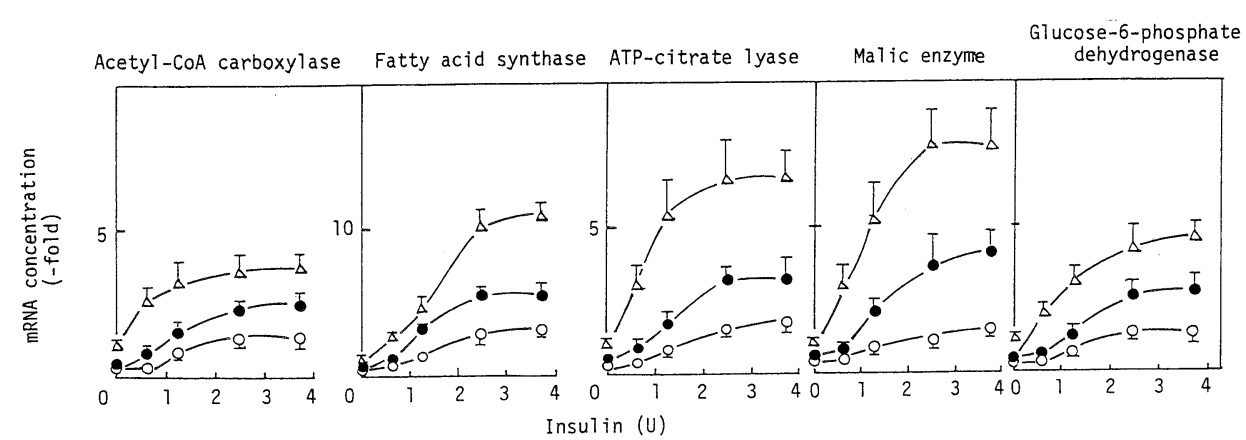

Fig. 1. Effects of insulin-treatment on mRNA concentrations of lipogenic enzymes in livers of diabetic rats fed corn oil. Streptozotocin diabetic rats fed on a $10 \%$ hydrogenated fat (triangle), 5\% hydrogenated fat plus 5\% corn oil (solid circle) or $10 \%$ corn oil (open circle) diet were injected with $0.625,1.25,2.50$, or $3.75 \mathrm{U}$ of Lente insulin per $100 \mathrm{~g}$ of body weight at $1700 \mathrm{~h}$. The animals were killed at $900-1000 \mathrm{~h}$ the next morning. The mRNA concentrations are normalized against diabetic rats of the fat-free diet group. A: Acetyl-CoA carboxylase, B: fatty acid synthase, C: ATP-citrate lyase, D: malic enzyme, E: glucose-6phosphate dehydrogenase. Significantly different among the dietary groups at $1.25,2.50$, and $3.75 \mathrm{U}$ insulin treatment, at $p<0.05$ at least. Mean $\pm \mathrm{SD}(n=$ 12).

Table 1. Effects of dietary fat type and pioglitazone treatment on lipogenic enzyme mRNA concentrations in the rat liver.

\begin{tabular}{lcc}
\hline Diet & $\begin{array}{c}\text { Acetyl-CoA carboxylase } \\
\text { (fold) }\end{array}$ & $\begin{array}{c}\text { Fatty acid synthase } \\
\text { (fold) }\end{array}$ \\
\hline Fat-free & $1.00 \pm 0.23^{\mathrm{a}}$ & $1.00 \pm 0.12^{\mathrm{a}}$ \\
Hydrogenated fat & $0.88 \pm 0.04^{\mathrm{a}}$ & $0.81 \pm 0.11^{\mathrm{a}}$ \\
Hydrogenated fat+pioglitazone & $0.76 \pm 0.07^{\mathrm{a}}$ & $0.77 \pm 0.11^{\mathrm{a}}$ \\
Olive oil & $1.05 \pm 0.25^{\mathrm{a}}$ & $0.78 \pm 0.16^{\mathrm{a}}$ \\
Corn oil & $0.55 \pm 0.02^{\mathrm{b}}$ & $0.29 \pm 0.04^{\mathrm{b}}$ \\
Corn oil +pioglitazone & $0.77 \pm 0.16^{\mathrm{a} *}$ & $0.41 \pm 0.07^{\mathrm{b} *}$ \\
Fish oil & $0.35 \pm 0.12^{\mathrm{b}}$ & $0.21 \pm 0.01^{\mathrm{b}}$ \\
\hline
\end{tabular}

Streptozotocin diabetic rats fed on a fat-free or various kinds of fat diet for 5 days were injected with Lente insulin $(2.5 \mathrm{U} / 100 \mathrm{~g}$ body weight) at $1700 \mathrm{~h}$ and killed at 900-1000 $\mathrm{h}$ the next morning. ${ }^{1}$ Pioglitazone $(3 \mathrm{mg} / \mathrm{kg})$ was administered by orogastric tube each day for 5-7 days. The mRNA concentrations were normalized to the fat-free diet. Means with different superscript letters are significantly different among each of the dietary groups $(p<0.05)$. * Significantly different from no pioglitazone treatment $(p<0.05)$. Mean \pm SD $(n=5-6)$.

\section{Effects of pioglitazone on $m R N A$ concentrations}

After diabetic rats fed corn oil were treated with insulin, the PUFA-mediated suppression of mRNA concentrations of acetyl-CoA carboxylase and fatty acid 


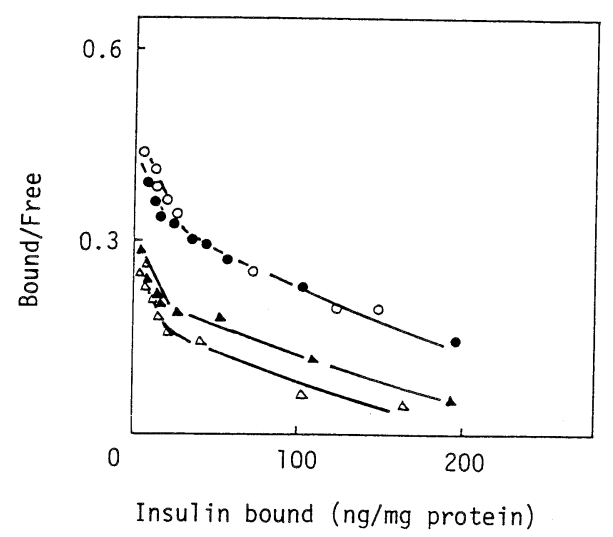

Fig. 2. Insulin binding to receptors from livers of rats fed corn oil (triangle) or hydrogenated fat (circle). The Scatchard plots were obtained from the insulin binding data. Pioglitazone $3 \mathrm{mg} / \mathrm{day} / \mathrm{kg}$ was administered by orogastric tube to diabetic rats fed the 5\% corn oil or hydrogenated fat diet for 5-7 days (solid symbols of each group). The experiments were performed using 5 animals for each group, and data for one of the typical results are shown.

synthase was restored to a greater extent in the pioglitazone treated animals than in the non-treated rats (Table 1). However, no significant effects of the pioglitazone treatment on the mRNA concentrations were seen in the animals fed hydrogenated fat.

Effects of pioglitazone on insulin binding to receptors and receptor phosphorylation

The insulin binding to receptors was lower in the corn oil diet group than in the hydrogenated fat group (Fig. 2). Pioglitazone treatment did not increase insulin binding in the hydrogenated fat group but did in the corn oil group. However, the Scatchard plots revealed that insulin binding affinity to receptors was not affected by dietary fat type or by pioglitazone treatment.

The insulin-stimulated autophosphorylation of the $\beta$-subunit of insulin receptors of livers was significantly decreased by corn oil feeding in comparison with the hydrogenated fat diet group, as shown in Fig. 3 (upper). The PUFA-mediated suppression was partially restored by the pioglitazone treatment. Moreover, a similar result was observed in the insulin receptor kinase activities with exogenous substrate (Glu4 : Tyr1). The results of ${ }^{32} \mathrm{P}$ incorporation to the substrate are shown in Fig. 3 (lower).

\section{DISCUSSION}

When diabetic rats adapted to a $10 \%$ hydrogenated fat, $5 \%$ corn oil $(+5 \%$ hydrogenated fat) or $10 \%$ corn oil diet were injected with insulin, the insulin 

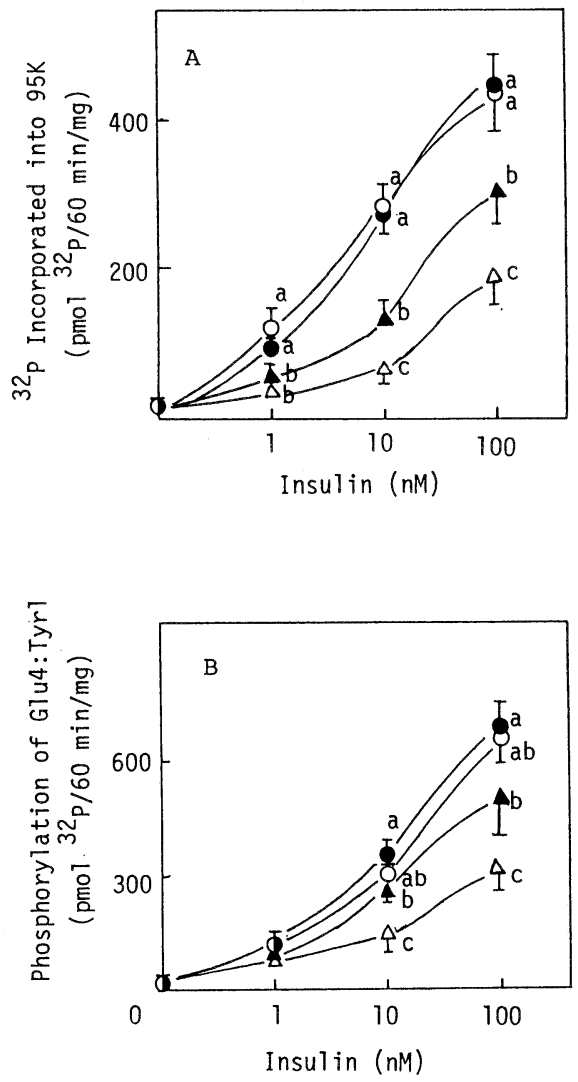

Fig. 3. Autophosphorylation of insulin receptors (A) and phosphorylation of Glu : Tyr by insulin receptors (B) of rat livers. (A) The lectin-purified insulin receptors of diabetic rat livers were preincubated with different concentrations of insulin and then incubatd with $\left[\gamma_{-}{ }^{32} \mathrm{P}\right] \mathrm{ATP}$. The samples were subjected to SDS-PAGE. ${ }^{32} \mathrm{P}$ incorporation into the $\beta$-subunit of insulin receptors $(95,000$ $M_{\mathrm{r}}$ ) was measured for autophosphorylation. (B) After incubation of insulin receptors with different concentrations of insulin, phosphorylation was initiated by adding $\left[\gamma_{-}^{32} \mathrm{P}\right] \mathrm{ATP}, \mathrm{Mg}^{2+}$, and Glu4:Tyr1. The circles show data for the hydrogenated fat diet group and the triangles for the corn oil group. Solid symbols of each group show data for pioglitazone treatment. Means with different superscript letters are significantly different among data at 1,10 , or 100 nM insulin treatment $(p<0.05)$. Experiments were performed using 6 animals for each group (Mean $\pm \mathrm{SD})$.

dose-dependent inductions of lipogenic enzyme mRNAs were markedly reduced with increasing dietary corn oil in a dose-dependent fashion. The PUFA-mediated suppression of the mRNA concentrations was partially restored by pioglitazone treatment. Sugiyama et al. (15) and Ikeda et al. (16) reported that the effects of 
pioglitazone on insulin-dependent glucose oxidation and lipogenesis seem to be due to increased insulin sensitivity. However, the effects were not accompanied by any changes in insulin binding, suggesting that pioglitazone can improve glucose and lipid metabolism by reducing insulin resistance on the post-binding system (15). Kobayashi et al. (19) also reported that pioglitazone treatment did not change insulin binding to receptors but increased the insulin receptor autophosphorylation and kinase activity toward exogenous substrate, suggesting that pioglitazone increase insulin sensitivity in part by activating kinase of the receptors. Cremel et al. (18) reported that linoleic acid decreased the insulin binding to receptors in rat hepatoma cells, and tyrosine kinase activity of partially purified receptors from the cells was also decreased with the changes in insulin action.

On the other hand, we have recently found that suppression of lipogenic enzyme gene expression by PUFA in genetically obese rats, which were less sensitive to insulin $(15,16)$, was less than that of lean rats, possibly due to a defect of insulin binding to receptors (17). It was suggested that PUFA-mediated regulation of lipogenic enzyme gene expression may be involved in the function of insulin receptors.

In the present experiment, we have found that the insulin binding to receptors and also insulin receptor autophosphorylation and kinase activities toward exogenous substrate were decreased by feeding polyunsaturated fat. The PUFAmediated suppression of insulin receptor autophosphorylation and kinase activities was partially restored by pioglitazone treatment. The PUFA-mediated suppression of insulin binding to receptors was also restored by pioglitazone treatment. The pioglitazone treatment also partially restored the PUFA-mediated suppression of lipogenic enzyme gene expression. As a result of the present study and previous studies $(16-19)$, it is suggested that PUFA-mediated suppression of insulindependent gene expression of lipogenic enzymes can be primarily ascribed to insulin binding to receptors, and also to insulin receptor phosphorylation and/or signal transduction. Thus, it is postulated that the PUFA-mediated suppression of the insulin-dependent lipogenic enzyme gene expression can by involved in the function of insulin receptors. Moreover, PUFA appears to suppress the lipogenic enzyme gene expression stimulated by insulin.

This work was supported in part by Japan Private School Promotion Funds. We wish to thank Dr. Hitoshi Ikeda (Pharmaceutical Research Division, Takeda Chemical Industries, Ltd.) for the generous gift of pioglitazone.

\section{REFERENCES}

1) Fukuda, H., Katsurada, A., and Iritani, N. (1992): Effects of nutrients and hormones on gene expression of ATP-citrate lyase in rat liver. Eur. J. Biochem., 209, 217-222.

2) Katsurada, A., Iritani, N., Fukuda, H., Matsumura, Y., Nishimoto, N., Noguchi, T., and Tanaka, T. (1990): Effects of nutrients and hormones on transcriptional and 
post-transcriptional regulation of acetyl-CoA carboxylase in rat liver. Eur. J. Biochem., 190, 435-441.

3) Katsurada, A., Iritani, N., Fukuda, H., Matsumura, Y., Nishimoto, N., Noguchi, T., and Tanaka, T. (1990): Effects of nutrients and hormones on transcriptional and post-transcriptional regulation of fatty acid synthase in rat liver. Eur. J. Biochem., 190, 427-433.

4) Katsurada, A., Iritani, N., Fukuda, H., Matsumura, Y., Nishimoto, N., Noguchi, T., and Tanaka, T. (1989): Effects of nutrients and insulin on transcriptional and post-transcriptional regulation of glucose-6-phosphate dehydrogenase synthesis in rat liver. Biochim. Biophys. Acta, 1006, 104-110.

5) Katsurada, A., Iritani, N., Fukuda, H., Noguchi, T., and Tanaka, T. (1987): Influence of diet on the transcriptional and post-transcriptional regulation of malic enzyme induction in the rat liver. Eru. J. Biochem., 168, 487-491.

6) Clarke, S. D., Armstrong, M. K., and Jump, D. B. (1990): Dietary polyunsaturated fat uniquely suppress rat liver fatty acid synthase and S14 mRNA content. J. Nutr., 120, 225-231.

7) Fukuda, H., Katsurada, A., and Iritani, N. (1992): Nutritional and hormonal regulation of mRNA levels of lipogenic enzymes in primary cultures of rat hepatocytes. J. Biochem. (Tokyo), 111, 25-30.

8) Girard, J., Perdereau, D., Foufelle, F., Prip-Buus, C., and Ferre, P. (1994): Regulation of lipogenic enzyme gene expression by nutrients and hormones. FASEB J., 8, 3642.

9) Limatta, M., Towle, H. C., Clarke, S., and Jump, D. B. (1994): Dietary polyunsaturated fatty acids interfere with the insulin/glucose activation of L-pyruvate kinase gene expression. Mol. Endocrinol., 8, 1147-1153.

10) Jump, D. B., Clarke, S. D., MacDougald, O., and Thelen, A. (1993): Polyunsaturated fatty acids inhibit S14 gene transcription in rat liver and cultured hepatocytes. Proc. Natl. Acad. Sci. U.S.A., 90, 8454-8458.

11) Kimberly, Z. L., and Towle, H. C. (1993): Carbohydrate regulation of the rat L-pyruvate kinase gene requires two nuclear factors: LF-A1 and member of the c-myc family. J. Biol. Chem., 268, 12787-12795.

12) Bergot, M.-O., Diaz-Guerra, M.-J. M., Puzenat, N., Raymondjean, M., and Kahn, A. (1992): cis-Regulation of the L-pyruvate kinase gene promoter by glucose, insulin and cyclic AMP. Nucl. Acids Res., 20, 1871-1878.

13) Shih, H., and Towle, H. C. (1994): Definition of the carbohydrate response element of the rat S14 gene. J. Biol. Chem., 269, 9380-9387.

14) Moustid, N., Scott Beyer, R., and Sul, H. S. (1994): Identification of an insulin response element in the fatty acid synthase promoter. J. Biol. Chem., 269, 5629-5634.

15) Sugiyama, Y., Taketomi, S., Shimura, Y., Ikeda, H., and Fujita, T. (1990): Effects of pioglitazone on glucose and lipid metabolism in Wistar fatty rats. Arzneim.-Forsch./ Drug Res., 40, 263-267.

16) Ikeda, H., Taketomi, S., Sugiyama, Y., Shimura, Y., Sohda, T., Meguro, K., and Fujita, T. (1990): Effects of pioglitazone on glucose and lipid metabolism in normal and insulin resistant animals. Arzneim.-Forsch./Drug Res., 40, 156-162.

17) Iritani, N., Hosomi, H., Fukuda, H., and Ikeda, H. (1995): Polyunsaturated fatty acid regulation of lipogenic enzyme gene expression in liver of genetically obese rat. 
Biochim. Biophys. Acta, 1225, 1-8.

18) Cremel, G., Fickova, M., Klimes, I., Leray, C., Leray, V., Meuillet, E., Roques, M., Staedel, C., and Hubert, P. (1993): Lipid modulation of insulin receptor tyrosine kinase activity in cultured cells, animals, and reconstituted systems. Ann. N.Y. Acad. Sci., 683, 164-171.

19) Kobayashi, M., Iwasaki, M., Egawa, K., and Shigeta, Y. (1992): Pioglitazone increases insulin sensitivity by activating insulin receptor kinase. Diabetes, 41, 476483.

20) Kletzien, R. F., Clarke, S. D., and Ulrich, R. (1991): Enhancement of adipocyte differentiation by an insulin-sensitizing agent. Am. Soc. Pharm. Exp. Ther., 41, 393398.

21) Hofmann, C. A., Edwards, C. W., III, Hillman, R. M., and Colca, J. R. (1992): Treatment of insulin-resistant mice with the oral antidiabetic agent pioglitazone: Evaluation of liver GLUT2 and phosphoenolpyruvate carboxykinase expression. Endocrinology, 130, 735-740.

22) Iritani, N., Nagashima, K., and Fukuda, H. (1986): Effects of dietary proteins on lipogenic enzymes in rat liver. J. Nutr., 116, 190-197.

23) Chomczyski, P., and Sacchi, N. (1987): Single-step method of RNA isolation by acid guanidium thiocyanate-phenol-chloroform extraction. Anal. Biochem., 163, 156-159.

24) Kadowaki, T., Kasuga, M., Akanuma, Y., Ezaki, O., and Takaku, F. (1984): Decreased autophosphorylation of the insulin receptor-kinase in streptozotocin-diabetic rats. J. Biol. Chem., 259, 14208-14216.

25) Hedo, J. A., Harrison, L. C., and Roth, J. (1981): Binding of insulin receptors to lectins: Evidence for common carbohydrate determinants on several membrane receptors. Biochemistry, 20, 3385-3393.

26) Freidenberg, G. R., Klein, H. H., Cordera, R., and Olefsky, J. M. (1985): Insulin receptor kinase activity in rat liver: Regulation by fasting and high carbohydrate feeding. J. Biol. Chem., 260, 12444-12453.

27) Laemmli, U. K. (1970): Cleavage of structural proteins during the assembly of the head of bacteriophage $\mathrm{T}_{4}$. Nature, 227, 680-685.

28) Klein H. H., Freindenberg, G. R., Cordera, R., and Olefsky, J. M. (1985): Substrate specificities of insulin and epidermal growth factor receptor kinases. Biochem. Biophys. Res. Commun., 127, 254-263.

29) Snedecor, G. W., and Cochram, W. G. (1967): Statistical Methods, Iowa State University Press, Ames, IA, pp. 285-338. 